\title{
PEMIKIRAN AKHLAK MENURUT SYAIKH UMAR BIN AHMAD BARADJA
}

\author{
Abd. Adim \\ Fakultas Ushuluddin dan Humaniora \\ IAIN Antasari Banjarmasin \\ Diterima tanggal 5 Oktober 2016 / Disetujui tanggal 29 Oktober 2016
}

\begin{abstract}
It is important to deepen Akblak teachings through seeing a figure of Ulama, who has a high integrity between knowledge and akblak. Syekh Umar Ahmad Baradja is an Ulama who has a good character and he was very productive to make a lot of wiritings. Some of them are seperti Al-Akblaq Lil Banin, kitab Al-Akblaq Lil Banat, kitab Sullam Fiqih, kitab 17 Jaubarah, dan kitab Ad'iyah Ramadhan. All of them were written in Arabic language, since 1950 were used as a main book in almost Islamic boarding school curriculumin Indonesia. He carved Indonesian Santri's character indirectly by bis books. These books (Al-Akblaq Lil Banin and kitab Al-Akblaq Lil Banat) are as references for teachers in giving students external and internal education to control their attitude and behavior in daily life. Especially, when they are in public society and worship. The special things in his books are they made guidance about character (Akblak) in two versions. One version is for boys and the other is for girls. The versions were made according to the needs of boys and girls to create a perfect character (Akblak alKarimah) to Allah and His creations. In the book also provided about some du'a (prayer text) and good actions, which had exemplified by Prophet Muhammad (pbuh) based on Qur'an and Sunnah. Syekh Umar Ahmad Baradja had told that before we come into mystical world or spiritual, we should learn about Akblak teachings comprehensively. Likewise, who does good actions in this world, he will get matchless happiness. There is a harmony relationship between theservant and his God. It is the meaning of ethics in Sufism performance. We can take the model from the fabulous figure, who was able to relieve someone's thirst in his heart and gave a light to the way to Allah.
\end{abstract}

Kata kunci: Syaikh Umar bin Ahmad Baradja, Ilmu Akhlak, dan Pengamalan.

\section{Pendahuluan}

Seiring berjalannya waktu dan bergantinya hari perlu adanya perubahan pada diri manusia ke arah yang lebih baik dan suci, untuk meraih kemulian di sisi Sang Maha Pencipta sebagai tujuan utama, sebagaimana hadis yang disabdakan oleh Baginda Nabi Besar Muhammad saw. :

\section{من كان يومهه خيرا من أمسه فهو رابح، ومن كان يومه مثل أمسه فهو مغبون ومن كان يومه شرا من أمسه فهو ملعون}

"Barangsiapa yang barinya (hari ini) lebih baik dari sebelumnya, maka ia telah beruntung, dan barang siapa harinya seperti sebelumnya, maka ia telah merugi, dan barang siapa yang bariny lebih jelek dari sebelumnya, maka ia tergolong orang-orang yang terlaknat"

Derajat hadits di atas ada yang mengatakan maudhu' (palsu) dan ada menyatakan dha'if namun ada hadits yang derajatnya marfu' yang memiliki arti mirip dengan hadits di atas yaitu :

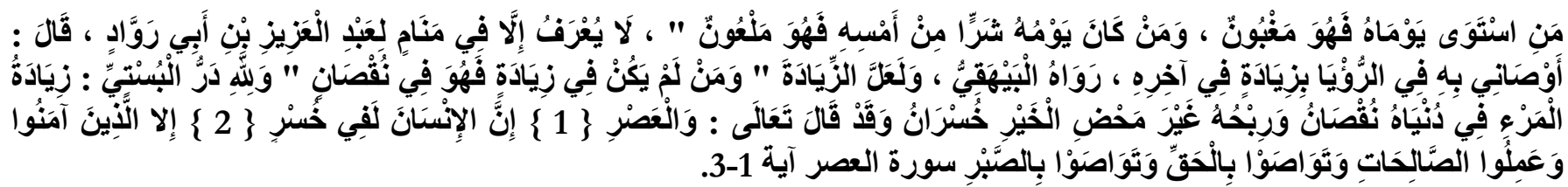

"Barangsiapa yang dua harinya (hari ini dan kemarin) sama maka ia telah merugi, barangsiapa yang harinya lebih jelek dari hari sebelumny maka ia tergolong orang-orangyang terlaknat" 
Asal usul hadis ini tidak diketahui, kecuali dalam mimpinya 'Abd 'Aziz bin Abi Rawad, ia berkata bahwa "Nabi berwasiat kepadaku dalam sebuah mimpi, kemudian disebutkan kata tambahan di akhirnya" (HR. al-Baihaqy), kemungkinan isi tambahannya adalah "Barangsiapa yang tidak terdapat tambahan amal kebaikan di harinya maka ia dalam kekurangan. ${ }^{1}$

Oleh sebab itu orang yang sekarang lebih buruk ketimbang kemarin termasuk orang yang celaka, dan jika sekarang sama dengan hari kemarin termasuk orang yang merugi dan orang yang hari ini lebih baik dari kemarin termasuk orang yang beruntung.

Dari pijakan inilah perlunya mengolah perilaku sesuai dengan tuntunan agama, sehingga manusia mengetahui betapa pentingnya amal kebajikan yang mesti kita tambah hari demi hari. Dan kesemuanya bisa kita jalani dari bimbingan sang pencipta melalui para Rasulnya untuk menjadi suri tauladan atau ajaran akhlak dalam kehidupan sosial dan ibadah, sebagaimana yang telah digambarkan dalam sebuah risalah kecil yang dituangkan oleh Syaikh Umar bin Ahmad Baraja.

\section{Pengertian Akhlak}

Ditinjau dari dua pendekatan linguistik dan teminologi, akhlak didefinisikan sebagai berikut: Secara linguistik: akhlak terambil dari asal kata اخلق - يخلق - إخلاق yang bisa diartikan

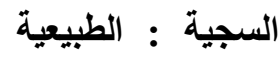
(perangai/tabiat/pembawaan/karakter) al-'adat (kebiasaan/kelaziman), al-maru'ah (peradaban yang baik), الدين (agama). ${ }^{2}$

Jika dicermati secara seksama olah kata pada makna اخلاق, maka akan ditemukan ketidaksingkronan dalam penamaan اخلاق, namun apabila kita mengacu dari sisi kebahasaan yang muncul dalam kata mashdar tersebut yaitu آخلاق tidak sesuai dengan kata termaktub di dalam kitab-kitab klasik maupun modern. Oleh karenanya ulama berpendapat bahwa kata اخلاق adalah termasuk kategori isim jamid bukan isim mustaq. ${ }^{3}$

Kemudian pendapat yang lain mengenai akar kata خَخلاق yُقُق yaitu terambil dari kata berarti budi pekerti, perangai, tingkah laku atau tabi’at, bisa juga kata itu terambil dari kata خَلْقُ yaitu kejadian yang mempunyai hubungan erat dengan خَالِّق Sang Maha Pencipta, sehingga terjadilah hubungan Tuhan dengan makhluk-Nya yang disebut dengan kata مَفْلُوْقُ bentuk gambaran jiwa beserta sifat-sifatnya sedangkan khalqu diartikan sebagai gambaran yang berbentuk dzabir seperti bentuk wajah, warna kulit dan tinggi rendahnya tubuh manusia dan sebagainya.

Secara terminologis: akhlak bisa dijabarkan dengan mengambil sebuah pandangan atau pendapat para ulama yang mengkaji tentang akhlak pada perspektif keterangan secara aplikatif. Sedangkan menurut pendapat

${ }^{1}$ www.piss-ktb.com/2012/02/307-hadits-setiap-hari-terbaik.html (18-03-2016).

${ }^{2}$ Abuddin Nata, Akblak Tasawnf, (Jakarta: PT. Grafindo Persada, 2012), 1. Lihat juga Jamil Shaliba, al-Mu'jam al-Falsafi, (Mesir: Dar al-Kiatab al-Mishri, 1978), Juz I. Luis Ma'luf, kamus al-Munjid, (Bairut: al-Makatabah al-Katulikiyah, t.t.), 194. Kamus Besar Indonesia, (Jakarta: Balai Pustaka , 1991), hal. 19. Ahmad Warson Munawwir, Al-Munawir, (Surabaya: Pustaka Progressif. 1984), 613.

${ }^{3}$ Abuddin nata, Akblak Tasawuf (Jakarta: PT. Grafindo Persada, 2012), 2. 
Ibnu Maskawaih beliau menjelaskan makna Akhlak yang keberagam arti bisa dipahami oleh para ulama salaf maupun khalaf, dengan menyimpulkan bahwa ma'na khuluq atau khalqu yang berarti akhlak adalah:

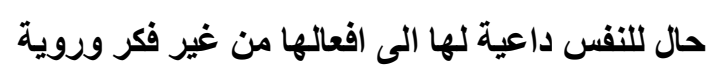

"keadaan jiwwa seseorang yang mendorong untuk melakukan perbuatan-perbuatan tanpa melalui pertimbangan pikiran terlebih dahulu."4

Menurut pemikiran Imam al-Ghazali yang selaras tentang makna Akhlak yang telah diuraikan dan dituangkan dalam makna khuluq yaitu:

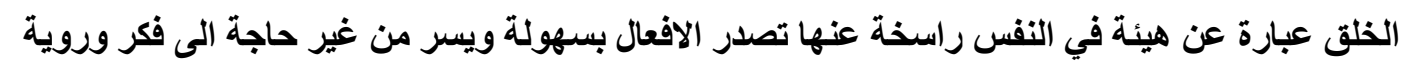

"Akblak yaitu sifat yang tertanam di dalam jiwa seseorang yang memunculkan perbuatan-perbuatan secara mudah atau spontan tanpa memerlukan pertimbangan." 5

Melihat uraian para ulama di atas maka kita bisa berpikir secara rasional bahwa akhlak bisa muncul pada diri manusia tergantung dari kebiasaan dan kekontinuitasnya prilaku seseorang, kendatipun banyak yang tidak disadari oleh seseorang tentang prilaku yang ternampak dalam kehidupannya manusia sering kali tidak memperhatikan tingkah laku dan berupaya menghiasinya dengan kebaikan semunya dikarenakan tidak memahami secara benar apa itu akhlak, sehingga terbitlah suatu pandangan di sisi orang yang menilai bahwa seseorang bisa dilihat atau disifatkan bahkan digambarkan menurut perangai, sifat dan tabi'at seseorang dalam tindakannya.

Kecenderungan manusia dalam melakukan tindakan pasti menjurus kepada dua akhlak, apabila mereka melakukan tindakan atau amal yang baik disebut dengan akhlak mahmudah dan jika mereka cenderung untuk melakukan amal yan jelek disebut dengan akhlak madæmumah, kemudian di dalam perputaran waktu kehidupan manusia ada cerminan dalam perubahan pola hidup manusia, sehingga tidak menutup kemukinan seseorang akan mengalami perubahan sikap, tindakan dan perilaku dalam kehidupannya. Namun bagi orang yang mempunyai iman yang tangguh, ia berada pada posisi akhlak mahmudah dan ia tidak terombangambingkan oleh zaman atau waktu dalam mengambil sikap dan bertindak, dia akan kuat dalam memegang teguh pendirian untuk menentukan sikap yang baik dengan selalu menghindar dari posisi akhlak madæmumah yaitu sikap yang tercela sebagai pintu masuk untuk mendekatkan dirinya kepada Allah swt.

\section{Biografi Syaikh Umar bin Ahmad Baradja}

Syaikh Umar bin Ahmad Baradja adalah seorang ulama yang memiliki akhlak yang sangat mulia. Beliau dilahirkan di Kampung Ampel Maghfur, pada tanggal 10 Jumadil Akhir 1331 H/17 Mei 1913 M. Sejak kecil beliau diasuh dan dididik kakeknya dari pihak ibu, Syaikh Hasan bin Muhammad Baradja, seorang ulama pakar ilmu nahwu dan fiqih. Syaikh Umar memiliki nisbah Baradja yang berasal dari Seiwun, Hadramaut, Yaman. Sebagai nama nenek moyangnya yang ke-18, Syaikh Sa'ad, yang berlaqab (berjulukan) 
Abi Raja' (yang selalu berharap). Mata rantai keturunan tersebut bertemu pada kakek Baginda Nabi Muhammad saw. yang kelima yang bernama Kilab bin Murrah. ${ }^{6}$

Penampilan Syaikh Umar sangat bersahaja, yang dihiasi dengan sifat-sifat ketulusan niat serta keikhlasan dalam segala amal perbuatan duniawi dan ukhrawi. Beliau juga mejabarkan akhlaq ahlul bait, keluarga Nabi dan para sahabat, dan berusaha unyuk selalu menteladani baginda Nabi Muhammad saw. dalam setiap tindakan dan perbuatan. Beliau tidak suka membangga-banggakan diri, baik tentang ilmu, amal, maupun ibadahnya. Semuanya itu karena sifat ketawadhu'annya dan rendah hati Syaikh Umar yang sangat tinggi.

Dalam beribadah, dia selalu istiqamah baik shalat fardhu maupun shalat sunnah qabliyah dan ba'diyah, bahkan shalat dhuha dan tahajud hampir tidak pernah beliau tinggalkan walaupun dalam bepergian. Kehidupannya dia usahakan untuk benar-benar sesuai dengan yang digariskan agama. Cintanya kepada keluarga Nabi saw. dan dzurriyyah atau keturunannya sangat terkenal tak tergoyahkan. Juga kepada para sahabat anak didik Rasulullah saw. Itulah pertanda bahwa keimanan yang beliau memiliki sangat teguh dan sempurna.

Pada saat sebelum mendekati ajalnya, Syaikh Umar sempat berwasiat kepada putra-putra dan anakanak didiknya agar selalu berpegang teguh pada ajaran Salaf al-Shalih, yaitu ajaran yang berasaskan Ablussunnah wal Jama'ah, yang dianut mayoritas kaum muslimin di Indonesia dan aliran Thariqah 'Alawiyyah, yang mata rantainya sampai bersambung kepada ahlul bait Nabi saw., para sahabat, yang semuanya bersumber dari Rasulullah saw.

Syaikh Umar mempunyai kecerdasan yang luar biasa yaitu memanfaatkan ilmu, waktu, umur, dan hartanya semata-mata di jalan Allah swt. sampai akhir hayatnya. Ia memenuhi panggilan Rabb-nya pada hari Sabtu malam Ahad tanggal 16 Rabiul as-Tsani 1411 H/3 November 1990 M pukul 23.10 WIB di Rumah Sakit Islam Surabaya, dalam usia 77 Tahun. Keesokan harinya Ahad ba'da Ashar beliau dimakamkan, setelah dishalatkan di Masjid Agung Sunan Ampel, yang diimami putranya sendiri serta sebagai khalifah (pengganti Syaikh Umar) yaitu Al-Ustadz Ahmad bin Umar Baradja. Jasad mulia itu dikuburkan di Makam Islam Pegirian Surabaya. Prosesi pemakamannya dihadiri oleh ribuan orang. ${ }^{8}$

a. Riwayat Pendidikan Syaikh Umar Baradja

Pada masa mudanya, Syaikh Umar bin Ahmad Baradja menuntut ilmu agama dan bahasa Arab dengan tekun, sehingga dia menguasai dan memahaminya. Berbagai ilmu agama dan bahasa Arab dia dapatkan dari ulama, ustadz, syaikh, baik melalui pertemuan langsung maupun melalui surat. Para alim ulama dan orang-orang shalih telah menyaksikan ketaqwaan dan kedudukannya sebagai ulama yang 'amil (ulama yang mengamalkan ilmunya).

${ }^{6}$ Muhammad Achmad Asseggaf. Sekelumit Riwayat Hidup Al-Ustadz. Umar bin Achmad Baradja (Surabay: Panitia Haul ke-V. 1995), 1.

${ }^{7}$ Majalah AlKisah No. 07/Tahun V/26 Maret - 8 April 2007, 88.

${ }^{8}$ Muhammad Achmad Asseggaf. Sekelumit Riwayat Hidup Al-Ustadz Umar bin Achmad Baradja (Surabaya: Panitia Haul ke-V. 1995), 11. 
Beliau adalah salah seorang alumnus yang berhasil dari pendidikan Madrasah Al-Khairiyyah di Kampung Ampel, Surabaya, yang didirikan dan dibina oleh al-Habib al-Imam Muhammad bin Ahmad al-Muhdhar pada 1895 M. yaitu Sekolah yang berasaskan Ablussunnah wal Jama'ah dan bermadzhab Syafi'i.

Guru-guru Syaikh Umar bin Ahmad Baradja, antara lain, al-Ustadz Imam al-Habr al-Qutub alHabib Abdul Qodir bin Ahmad Bilfaqih (Malang), Al-Ustadz Muhammad bin Husein Ba'bud (Lawang), al-Habib Abdul Qodir bin Hadi Assegaf, al-Habib Muhammad bin Ahmad Assegaf (Surabaya), al-Habib Alwi bin Abdullah Assegaf (Solo), al-Habib Ahmad bin Alwi al-Jufri (Pekalongan), al-Habib Ali bin Husein Bin Syahab, al-Habib Zein bin Abdullah Alkaff (Gresik), al-Habib Ahmad bin Ghalib alHamid (Surabaya), al-Habib Alwi bin Muhammad al-Muhdhar (Bondowoso), al-Habib Abdullah bin Hasan Maulachela, al-Habib Hamid bin Muhammad as-Sirry (Malang), Syaikh Robaah Hassunah AlKholili (Palestina), Syaikh Muhammad Mursyid (Mesir) - kedua guru terakhir adalah guru yang bertugas mengajar di Indonesia.

Guru-gurunya yang berada di luar negeri di antaranya, al-Habib Alwi bin Abbas al-Maliki, asSayyid Muhammad bin Amin al-Quthbi, as-Syaikh Muhmmad Seif Nur, as-Syaikh Hasan Muhammad alMasyath, al-Habib Alwi bin Salim al-Kaff, as-Syaikh Muhammad Said al-Hadrawi al-Makky (Mekkah), alHabib Muhammad bin Hadi Assegaf (Seiwun, Hadramaut, Yaman), al-Habib Abdullah bin Ahmad alHaddar, al-Habib Hadi bin Ahmad al-Haddar ('inat, Hadramaut, Yaman), al-Habib Abdullah bin Thahir al-Haddad (Geidun, Hadaramaut, Yaman), al-Habib Abdullah bin Umar asy-Syatiri (Tarim, Hadramaut, Yaman), al-Habib Hasan bin Ismail bin Syaikh Abu Bakar (inat, Hadramaut, Yaman), al-Habib Ali bin Zein al-Hadi, al-Habib Alwi bin Abdullah bin Syahab (Tarim, Hadramaut, Yaman), al-Habib Abdullah bin Hamid Assegaf (Seiwun, Hadramaut, Yaman), al-Habib Muhammad bin Abdullah al-Haddar (Al-Baidhaa, Yaman), al-Habib Ali bin Zein Bilfagih (Abu Dhabi, Uni Emirat Arab), as-Syaikh Muhammad Bakhit alMuthii'i (Mesir), Sayyidi Muhammad al-Fatih al-Kattani (Faaz, Maroko), Sayyidi Muhammad alMunthashir al-Kattani (Marakisy, Maroko), al-Habib Alwi bin Thohir al-Haddad (Johor, Malaysia), Syaikh Abdul 'Aliim as-Shiddiqi (India), Syaikh Hasanain Muhammad Makhluf (Mesir), al-Habib Abdul Qodir bin Ahmad Assegaf (Jeddah, Arab Saudi). ${ }^{9}$

Beliau bertemu dengan guru-guru tersebut tidak hanya dalam proses belajar mengajar pada sebuah majelis, tetapi banyak dari mereka yang beliau hanya bertemu beberapa kali dan mengambil sedikit ilmu darinya sudah beliau anggap sebagai guru, inilah bukti dari sifat beliau yang tawadhu'. Bahkan tak sedikit dari mereka yang usia jauh lebih mudah dari beliau yang beliau jadikan sebagai guru. ${ }^{10}$ Sebagaimana perkataan yang disebutkan oleh sahabat Nabi sayyidina Ali Karamallabu Wajhah:

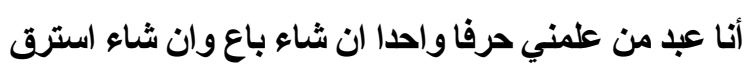

${ }^{9}$ Muhammad Ahmad Asseggaf, Sekelumit Riwayat Hidup Al-Ustadz Umar bin Achmad Baradja (Surabaya: Panitia Haul ke-V. 1995), 2-5.

${ }^{10}$ Hasil wawancara dengan Ustdaz. Mushtofa bin Ahmad Baradja (Cucu Syaikh Umar bin Ahmad Baradja), 16 Maret 
Artinya: Saya adalah hamba dari orang yang mengajariku satu buruf. Jikalau ia man menjualnya maka diperbolehkan dan jikalau mau membebaskannya maka boleh juga kemudian maka jika ia minat boleh memperbudaknya. ${ }^{11}$

b. Ilmu-ilmu yang Dikuasai dan Karya-karya Syaikh Umar Baradja

Kepandaian Syaikh Umar Baradja dalam bidang karya tulis, disebabkan beliau menguasai bahasa Arab dan sastranya, ilmu tafsir dan hadits, ilmu fiqh dan tasawuf, ilmu sirah dan tarikh. Ditambah penguasaan bahasa Belanda dan bahasa Inggris. ${ }^{12}$

Hampir semua santri di pesantren pernah mempelajari buku-buku karya Syaikh Umar Baradja dari Surabaya. Sudah sekitar 11 judul buku yang diterbitkan, seperti Al-Akblaq Lil Banin, kitab AlAkblaq Lil Banat, kitab Sullam Fiqih, kitab 17 Jaubarah, dan kitab Ad'iyah Ramadhan. Semuanya diterbitkan dalam bahasa Arab dan sejak 1950 telah digunakan sebagai buku kurikulum di hampir seluruh pondok pesantren di Indonesia. Secara tidak langsung Syaikh Umar bin Ahmad Baradja ikut serta dalam mengukir akhlak-akhlak para santri di Indonesia.

Buku-buku karya Syaikh Umar tersebut pernah dicetak di Kairo, Mesir, pada tahun 1969 atas biaya Syaikh Siraj Ka'ki seorang dermawan Mekkah, yang dibagikan secara cuma-cuma ke seluruh dunia Islam. Syukur alhamdulillah, atas ridha dan niatnya agar buku-buku ini menjadi jariyah dan bermanfaat luas, pada 1992 telah diterbitkan buku-buku tersebut ke dalam bahasa Indonesia, Jawa, Madura, dan Sunda.

Selain menulis buku pelajaran, Syaikh Umar juga menulis syair- syairnya dalam bahasa Arab dengan sastranya yang tinggi. Menurut ustadz Mushtofa bin Ahmad bin Umar Baradja, cucu dari putra tertuanya karangan buku dan gubahan syairnya cukup banyak dan belum sempat dibukukan. Selain itu, masih banyak karya lain, seperti masalah keagamaan, yang masih bertuliskan tangan dan tersimpan rapi dalam perpustakaan keluarga. ${ }^{13}$

c. Kiprah dan Dakwah Ustadz Umar Baradja

Syaikh Umar mengawali karirnya mengajar di Madrasah Al-Khairiyah Surabaya tahun 1935-1945 M. dan berhasil menelurkan beberapa ulama dan asatidz yang telah menyebar ke berbagai pelosok tanah air. Di Jawa Timur antara lain, almarhum al-Ustadz Ahmad bin Hasan Assegaf, almarhum al-Habib Umar bin Idrus al-Masyhur, almarhum al-Ustadz Ahmad bin Ali Babgei, al-Habib Idrus bin Hud Assegaf, al-Habib Hasan bin Hasyim al-Habsyi, al-Habib Hasan bin Abdul Qodir Assegaf, al-Ustadz Ahmad Zaki Ghufron, dan alUstadz Dja'far bin Agil Assegaf.

2014.

${ }^{11}$ Hasil wawancara dengan Ustdaz. Mushtofa bin Ahmad Baradja (Cucu Syaikh Umar bin Ahmad Baradja), 16 Maret

${ }^{12}$ Muhammad Ahmad Assegaf, sekelumit Riwayat Hidup Al-Ustadz Al-Ustadz Umar bin Achmad Baradja (Surabaya: Panitia Haul ke-V. 1995), 8.

${ }^{13}$ Hasil wawancara dengan Ustdz. Mushtofa bin Ahmad Baradja (Cucu Syaikh Umar bin Ahmad Baradja), 16 Maret 
Kemudian beliau pindah mengajar dari Madrasah Al-Khairiyah, Bondowoso. Berlanjut mengajar di Madrasah Al-Husainiyah, Gresik tahun 1945-1947 M. Lalu mengajar di Rabithah Al-Alawiyyah, Solo, tahun 1947-1950 M. Mengajar di Al-Arabiyah Al-Islamiyah, Gresik tahun 1950-1951 M. Setelah itu, tahun 1951-1957, bersama al-Habib Zein bin Abdullah al-Kaff, memperluas serta membangun lahan baru, karena sempitnya gedung lama, sehingga terwujudlah gedung yayasan badan wakaf yang di beri nama Yayasan Perguruan Islam Malik Ibrahim.

Selain mengajar di lembaga pendidikan, Syaikh Umar juga mengajar di rumah pribadinya, pagi hari dan sore hari, serta majelis taklim atau pengajian rutin malam hari. Karena sempitnya tempat dan banyaknya murid, dia berusaha mengembangkan pendidikan itu dengan mendirikan Yayasan Perguruan Islam atas namanya al-Ustadz Umar Baradja. Ini sebagai perwujudan hasil pendidikan dan pengalamannya selama 50 tahun. Hingga kini masih berjalan di bawah asuhan Ustadz Mushtofa bin Ahmad bin Umar Baradja, cucu beliau. Memang patut diberi penghargaan untuk sosok Syaikh Umar sebelum diasuh oleh al-Ustadz Ahmad bin Umar Baradja sudah melahirkan alumni-alumni yang sukses di bidang dakwah, di antaranya al-Habib Idrus bin Muhammad Alaydrus. ${ }^{14}$

Amal ibadahnya meluas ke bidang lain, sehingga memerlukan dana yang cukup besar, dia juga menggalang dana untuk kebutuhan para janda, fakir miskin, dan yatim piatu khususnya para santrinya, agar mereka lebih berkonsentrasi dalam menimba ilmu. Menjodohkan wanita-wanita muslimah dengan pria muslim yang baik menurut pandangannya, sekaligus mengusahakan biaya perkawinannya dengan dukungan dana dari al-Habib Idrus bin Umar Alaydrus.

Salah satu karya monumentalnya adalah membangun Masjid Al- Khair (dana karya I-48/50, Surabaya) pada tahun 1971 M, bersama K.H. Adnan Chamim, setelah mendapat petunjuk dari al-Habib Sholeh bin Muhsin al-Hamid (Tanggul) dan al-Habib Zein bin Abdullah al-Kaff (Gresik). Masjid ini sekarang digunakan untuk berbagai kepentingan dakwah masyarakat Surabaya.

Dalam buku "Kunjungan Habib Alwi Solo kepada Habib Abubakar Gresik, catatan Habib Abdul Qadir bin Hussein Assegaf " disebutkan,”... kami (rombongan Habib Alwi bin Alwi Al- Habsyi) berkunjung ke rumah Syaikh Umar bin Ahmad Baradja (di Surabaya). Kami dengar saking senangnya, ia sujud syukur di kamar khususnya. Ia meminta Sayyidi Alwi untuk membacakan doa dan Fatihah.”

Sifat wara'-nya sangat tinggi. Perkara yang meragukan dan syubhat dia tinggalkan, sebagaimana meninggalkan perkara-perkara yang haram. Dia juga selalu berusaha berpenampilan sederhana. Sifat ghirah Islamiyah (semangat membela Islam) sangat tinggi serta sifat iri dalam kehidupan beragamanya sangat kuat dalam jiwanya. Konsistensinya dalam menegakkan amar ma'ruf nahi munkar tidak diragukan, misalnya dalam menutup aurat, khususnya aurat wanita, dia sangat keras dan tak kenal kompromi. Dalam membina anak didiknya, pergaulan bebas antara laki-laki dan perempuan dia tolak keras. Juga bercampurnya murid laki-laki dan perempuan dalam satu kelas. ${ }^{15}$

${ }^{14}$ Hasil wawancara dengan Ustdz. Mushtofa bin Ahmad Baradja (Cucu Syaikh Umar bin Ahmad Baradja), 16 Maret 


\section{Pemikiran Akhlak dalam Kitab Akhlakul Li al-Banin wal Banat dalam Dimensi Tasawuf}

Syaikh Umar bin Ahmad Baradja menuangkan pemikirannya tentang Akhlak di dalam kitab Akblak li al-Banin wa Banat yang merupakan sebuah karya yang sangat fenomenal, yang mana kitab tersebut dipakai oleh kalangan santri di pondok Pesantren pada umumnya terlebih-lebih di Indonesia, khususnya Pondok Pesantren yang ada di Pulau Jawa. Kitab beliau ini yang menjadi rujukan oleh para pengasuh dalam pendidikan zhahir maupun bathin si murid untuk bisa mengontrol sikap dan tingkah laku santri dalam kehidupan sehari-harinya, terutama pada ruang lingkup bermasyarakat dan beribadah. Keunikan dan kelebihan Syaikh Umar dalam karyanya mengenai bimbingan tentang Akhlak, beliau membuat dua versi yang sesuai dengan kebutuhan anak laki-laki dan anak-anak perempuan untuk mewujukan akblak al-karimah yang sempurna, baik itu berhubungan dengan Tuhan/sang khalik maupun dengan makhluk, juga dalam sajian kitab beliau memuat tentang doa-doa dan amalan yang mengacu pada al-Qur'an dan as-Sunnah (Hadis) Rasulullah saw.

Demikian contoh bimbingan Akhlak pada kitab beliau, dari salah satu nasehatnya kepada seorang wanita yaitu putri sekarang akan menjadi ibu di masa mendatang. Apabila ia besar dalam Akhlak yang mulia dan tumbuh dengan pendidikan yang benar, maka ia pun akan menjadi sekolah dasar dimana anak-anak menerima dasar-dasar kebaikan dan tonggak-tonggak kebesaran serta kemuliaan darinya. ${ }^{16}$

Syaikh Umar bin Ahmad baradja juga sangat peduli kepada bangsa dan negara dengan membawa ajaran Akhlak sebagai kontribusi pemikirannya, sebagaimana yang telah disebutkan dalam karya beliau kitab Akblak li al-Banin yaitu: Umat suatu bangsa dinilai baik dan buruknya dari akhlak atau moralnya, sekali-kali bukan dipandang dari kekayaan dan kebagusan wajah mereka. Sebagai modal utamanya adalah mendidik putra-putri bangsa kita dengan akhlak budi pekerti yang luhur, di samping ilmu-ilmu pengetahuan yang lain. Dengan demikian nantinya masa depan mereka akan menjamin nama baik bangsa kita. Jika kita mau mengkaji isi pemikiran Syaikh Umar bin Ahmad Baradja dalam kitab yang kecil, tipis dan berjilid maka semua kalangan bisa mengambil pelajaran guna memperbaiki akhlak dengan bercermin kepada anak kecil.

Terkait dengan kajian tasawuf, akhlak merupakan akar untuk menumbuhkan dimensi spritualisme kaum sufi. Kemudian jika kita melihat dari sistem yang ada pada ajaran akhlak maka tasawuf bersenyawa dengan akhlak yang tidak akan bisa terpisahkan. Dengan mengacu pada akhlaklah maka muncul ajaran tasawuf akhlaqi. Begitulah pemikiran Syaikh Umar bin Ahmad Baradja dalam menjalani dimensi spritualnya dan seruan untuk masuk kedunia tasawuf dengan media dakwahnya baik dari karya-karyanya yang dibutuhkan oleh semua kalangan. Secara etimilogi tasawuf akhlaqi diartikan untuk pembersihan sikap atau tabi'at yang melekat pada diri seorang hamba. Sehingga terbitlah ajaran tasawuf akhlaqi yang tersebut pada sistem pembinaan akhlak sebagaimana susunan berikut:

\section{Takhalli}

Takhalli adalah pijakan pertama untuk melangkah menuju jalan spiritual yaitu berusaha mengosongkan diri dari sifat, tindakan dan perilaku yang terlarang/tercela. Caranya dengan memadamkan hawa nafsu yang

16Umar Baradja, bimbingan Akblak bagi Putri-Putri Anda, (Surabaya: YPI “Al-Ustadz Umar Baradja”, 1992), 7. 
tidak habis-habisnya menyala yang mendorong untuk melakukan perbuatan nista pada jiwa manusia dengan jalan menghindari segala bentuk perbuatan maksiat.

\section{Tahalli}

Tahalli adalah upaya untuk memenuhi kekosongan dari perbuatan tercela dengan mengisi dan menghiasi diri melalui latihan dan mebiasakan bersikap dan berprilaku dalam tindakan-tindakan yang terpuji.

3. Tajalli

Tajalli adalah upaya terakhir setelah melewati fase takhalli dan tahalli untuk memantapkan dan memperdalam materi dalam proses kesempurnaan dan kesucian jiwa, meskipun ada perbedaan sebagian kaum sufi bahwa kesempurnaan dan kesucian jiwa seluruhnya tergantung pada jalan yang satu yaitu mahabbah kepada Allah swt serta memperdalam rasa kecintaan itu sebagai wujud hamba yang berakhlak terhadap Tuhannya. ${ }^{17}$

Setelah kita kenal sistem akhlak dalam dimensi tasawuf maka jelas bahwa pemikiran Syaikh Umar bin Ahmad Baradja sangat diperlukan dalam mengaplikasikan etika dan moral manusia, terutama yang berhubungan dengan amalan-amalan spiritual atau dunia sufisme, selain itu akhlak juga bisa dijadikan sebagai rujukan dan fondasi yang kokoh dalam menapaktilasi perjalanan kaum sufisme, sehingga terungkaplah tabir secara mudah dalam dimensi spiritual sesuai dengan amal atau perbuatan seorang hamba untuk menempuh jalan menuju Allah swt. secara hakiki.

\section{Kesimpulan}

Pemikiran Syaikh Umar bin Ahmad Baradja tidak bisa diragukan lagi tentang pembangunan manusia baik secara moral maupun spiritual, terutama yang berkaitan dengan akhlak yang menjadi tolak ukur baik buruk keadaan seseorang hamba di sisi Tuhannya dan di mata makhluknya. Oleh karenanya setiap pemikiran Syaikh Umar bin Ahmad Baradja yang tertuang di dalam karyanya selaras dengan apa yang termaktub atau tertulis di dalam al-Quran dan as-Sunnah, serta sepakat ulama pada zamannya terlebih-lebih gurunya dan teman sejawatnya untuk memberikan pujian dan pengakuan secara nyata maupun tersirat bahwa beliau adalah sang pencerah akhlak para pemuda dan pemudi di masa sekarang dan di masa akan datang yang diharapkan dewasanya kelak menjadi manusia yang sempurna.

Di sinilah cerminan etika dan amalan sufisme yang menjadi pendorong seorang hamba untuk mampu menjalin hubungan baik kepada sang maha pencipta melalui jalan akhlak. Setelah akhlak terbentuk secara sempurna maka seorang hamba akan merasakan makna hidup di dunia dengan penuh penghayatan akan arti hidup sebenarnya, dengan mengedepankan akblaq al-karimah sebagai landasan pokok dalam memperjuangkan diri untuk menjadi insan sejati. Sebagaimana diutaran oleh Syaikh Umar bin Ahmad Baradja di dalam karya-karyanya bisa kita simpulkan bahwa sebelum masuk ke alam mistik atau dunia spiritual, maka dituntut seseorang untuk mempelajari ajaran akhlak secara menyeluruh dengan mengkaji karya-karya orang-orang terdahulu seperti karya Syaikh Umar bin Ahmad Baradja yang sudah fenomenal,

${ }^{17}$ Ahmad Bangun Nasution \& Royani Hanum Siregar, Akblak Tasawnf : Pengeanalan, Pemahaman dan Pengaplikasiannya (Disertai Biografi Tokoh-Tokoh Sufi), (Jakarta: PT. Raja Garafindo, 2013), 30-31. 
yang sangat berpengalaman dalam mengarungi dunia sufisme. Karena melalui jalan etika atau akhlak akan mempermudah seseorang yang mau menempuh jalan spiritual guna meraih cinta Sang Maha Pencipta Yang Maha Rahman dan Rahim, sehingga manisnya beramal akan amalan akhirat laksana manisnya minum madu dan susu. Demikian pula melakukan amalan akan suatu amalan dunia dapat menghantarkan seseorang meraih kebahagian yang tiada tara, semuanya dikarenakan adanya unsur keharmonisan hubungan antara seorang hamba dan sang penciptanya. Inilah maksud etika dalam amalan sufisme yang kita ambil pada tokoh yang luar biasa yang mampu menyirami hati seorang hamba akan dahaganya dan menerangi jalan yang buram dalam menuju Tuhannya, yakni jalan Allah swt .

\section{DAFTAR PUSTAKA}

Ahmad Asseggaf, Muhammad. Sekelumit Riwayat Hidup Al-Ustadz Umar bin Achmad Baradja, Surabaya: Panitia Haul ke-V. 1995.

Al-Ghazali, Imam. Ihya Ulum Al-Din, Beirut: Dar Al-Figr. t.t.

Baradja, Umar, Bimbingan Akblak bagi Putri-Putri Anda, Surabaya: YPI “Al-Ustadz Umar Baradja. 1992.

Kamus Besar Indonesia, Jakarta: Balai Pustaka. 1991.

Majalah Al-Kisah. No. 07/Tahun V/26 Maret - 8 April 2007

Ma'luf, Luis. kamus al-Munjid, Bairut: al-Makatabah al-Katulikiyah. t.t.

Munawwir, Ahmad Warson. Al-Munawir, Surabaya: Pustaka Progressif. 1984.

Mushtofa, Ahmad Baradja. Hasil wawancara dengan (Cucu Syaikh Umar bin Ahmad Baradja). 16 Maret 2014.

Mustofa, H.A. Akhlak Tasawnf, Bandung: CV. Pustaka Setia, 2010.

Mulayati, Sri. et.al., Mengenal dan Memahami Tarekat-Tarekat Muktabarah di Indonesia. Jakarta: Kencana. 2005.

Nasution, Ahmad Bangun \& Siregar, Royani Hanum, Akblak Tasawnf: Pengeanalan, Pemahaman dan Pengaplikasiannya (Disertai Biografi Tokoh-Tokoh Sufi), Jakarta: PT. Raja Grafindo. 2013.

Nata, Abuddin. Akblak Tasawnf, Jakarta: PT. Grafindo Persada, 2012.

Shaliba, Jamil. al-Mu'jam al-Falsafi, Mesir: Dar al-Kitab al-Mishri. 1978.

www.piss-ktb.com/2012/02/307-hadits-setiap-hari-terbaik.html (18-03-2016) 